Journal of Engineering and Applied Sciences 15 (4): 1043-1051, 2020

ISSN: 1816-949X

(C) Medwell Journals, 2020

\title{
Experimental Study on Bearing Capacity of Soft Soil Stabilization using Overboulder Asbuton as Sub-Base Layer
}

\author{
Noor Dhani, Lawalenna Samang, Tri Harianto and A.R Djamaluddin \\ Department of Civil Engineering, Faculty of Engineering, Hasanuddin University, \\ Gowa, South Sulawesi Province, Indonesia
}

\begin{abstract}
Soil stabilization has been carried out to increase the mechanical capacity, so that, it is possible to bear the load of a construction. Generally, the stabilization is carried out with ash, cement and lime to trigger a pozzolan reaction that able to enhance the cohesion between the soil grains, thus, increasing the mechanical values of the soil. Buton island in Southeast Sulawesi, Indonesia has a large amount of about 627 million metric tons of asphalt deposit in many forms. In Indonesia, natural asphalt derived from Buton island was called Asbuton (Asphalt Buton). The Asbuton deposit divided into several types. One of the types is overboulder which about $30 \%$ of the total deposit of asbuton. Overboulder occurred naturally when limestone reacts with bitumen in the topsoil layer of asbuton itself, making it a waste material which could be used as stabilizer material, due to its lime content with low bitumen content at about below $2 \%$. In this study, the researchers are trying to analyze the behavior of soft soil stabilization using overboulder asbuton with and without activator using a plate bearing model test. The activator used in this study was water glass, polymer and iron oxide. Soil investigation started by obtaining the basic and mechanical properties of the soil, followed by element test using $\mathrm{CBR}$ and UCS value to determine the best composition. The value of the free compressive strength and the soil CBR value increases after the addition of overboulder and activation. Based on the result of the tests carried out, the optimum addition of the overboulder was $15 \%$, the UCS value of $3680.23 \mathrm{kNm}^{-2}$ and the CBR value of $38.22 \%$. The presence of an activator material increases the mechanical index of the soil. According to the test results, the highest bearing capacity value was achieved with a composition of $5 \%$ iron oxide and $15 \%$ overboulder. The unconfined compressive strength value increased by $113 \%$ compared to $15 \%$ overboulder-stabilized soil. The value of CBR increased by 165 over $15 \%$ overboulder-stabilized soil. Based on the results of the model tests show that the stabilized soil with activation of ferro oxide offers better performance as a subbase layer compared to stabilized soil and gravelly sand. With this result, the overboulder can be used as a substitute material for pavement foundation layers with high CBR values. And by using local content, there are opportunities for technical and financial benefits for future development.
\end{abstract}

Key words: California Bearing Ratio (CBR), unconfined compressive strength, overboulder asbuton, sand, tests, UCS

\section{INTRODUCTION}

One of the stability conditions of a structure is influenced by the state of the soil under the structure itself. The state of the soil that does not have a mechanical capacity that meets the specifications of a structure is a problem that often arises. For example, in the structure of the roadway. Poor soils will damage the pavement layer due to cyclic loads, axial loads and vibrations caused by vehicles passing over the structure. Therefore, in the pavement, a 3-layer system is generally created, namely the subgrade layer, subbase layer and base layer. This division is intended to create a better distribution of the load. In order to increase the mechanical value of the soil, soil stabilization is performed both mechanically and chemically. Soil stabilization is performed to increase the mechanical capacity, so that, it can withstand the construction load. Generally, the stabilization is carried out with fly ash, cement and lime to trigger a pozzolanic reaction that can increase the cohesion between the grains of the soil, thus, increasing the mechanical value of the soil.

Soil cement has been used as a massive fill to provide foundation strength and uniform support under large structures. An extensive laboratory testing program was conducted to determine static and dynamic design characteristics, liquefaction potential and durability of soil cement. Results showed that with only $5 \%$ cement content by dry weight, cohesion increased significantly and it was possible to obtain a material with enough strength to prevent liquefaction (Dupas and Pecker, 1979). Stabilized base or sub-base materials may be used to provide support

Corresponding Author: Noor Dhani, Department of Civil Engineering, Faculty of Engineering, Hasanuddin University, Gowa, South Sulawesi Province, Indonesia 
for either flexible or rigid pavements but are more frequently used with flexible pavements. The key to strength development in stabilized base or sub-base mixtures is in the matrix that binds the aggregate particles together. The strength of the matrix is affected by the cement material used in the mixture (FHA., 1980). The pozzolanic reaction process which can either be modest or quite substantial depending on the mineralogy of the soil is a long term process. This is because the process can continue as long as a sufficiently high $\mathrm{pH}$ is maintained to solubilize silicates and aluminates from the clay matrix and in some cases from the fine silt soil. These solubilized silicates and aluminates then react with calcium from the free lime and water to form calcium-silicate-hydrates and calcium aluminate-hydrates which are the same type of compounds that produce strength development in the hydration of Portland cement (Little and Nair, 2009). However, for the pavement of high traffic loads stabilization based on the sand with $10 \%$ cement is recommended. It is recommended that future research can mix more than one type of sand for the stabilization and find out the compressive strength for that mixed sand sample. On the other hand, sand with higher FM value and lower FM value can mix with different percentages (Mamun et al., 2016).

Soil stabilization is the alteration of the properties of soil to improve its engineering performance through its strength, stiffness, compressibility, permeability and work ability. In the last few decades, soil-cement stabilization has been more widely used in pavement construction compared to other methods because of the significant improvements it can make to soil properties. It is found that the engineering behavior of cement stabilized base and that of a granular base when under traffic loading are not similar (Bandara et al., 2017). The strength of road subgrades, soil bases and subbases are commonly assessed in terms of the California Bearing Ratio (CBR) which is dependent on the type of soil used and its density and moisture content. Thus, it is important to use correct test procedures to assess the properties of a cement stabilized road base (RDA., 1989).

In most applications, type I or type II Portland cement is normally used and the cement content can vary from $4-16 \%$ of the dry weight of soil. Generally, as the clay portion of the soil increases, the quantity of cement required also increases. The particle size distribution of ordinary Portland cement is quite well defined falling within a range of $0.5-100$ microns with a mean of 20 microns (Ingles and Metcalf, 1972). After it is stabilized, a soil layer will act as a soft and low strength concrete with linear elastic properties (Croney and Croney, 1997). The tensile stress at the bottom of the cement-treated layers can cause fatigue cracking. The elastic modulus and the tensile strain at the bottom of cement-treated layers are considered for the detailed analysis of a stabilized layer.

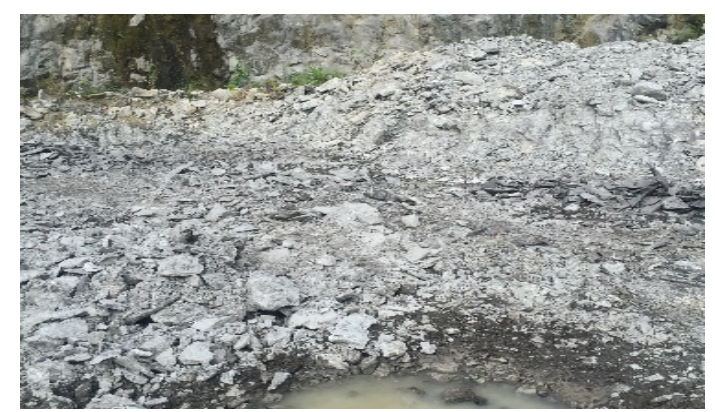

Fig. 1: Overboulder quarry

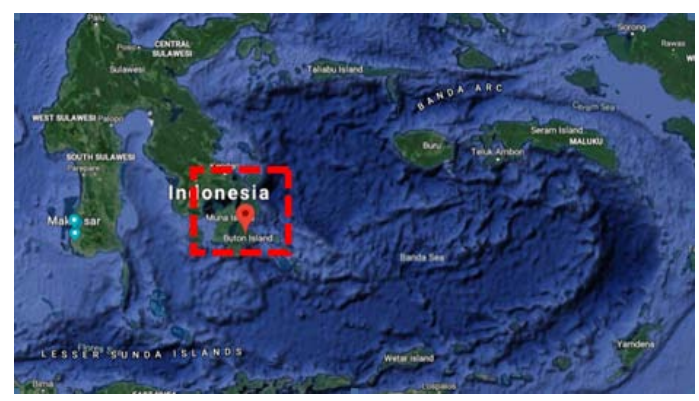

Fig. 2: Overboulder quarry location

The strength of the stabilized base and the subbase are commonly assessed using the Unconfined Compressive Strength (UCS) (TRL., 1977). Over Boulder Asbuton dominated by calcium content of $79.64 \%$ and silicon content of $9.63 \%$, so that, in the composition contained by these minerals can be used as pozzolanic material that can function as a binder and filler from soft soil material that can increase the bearing capacity of the material (Noor, 1994). However, compressive strength and durability were the two major approaches made with the Americans more inclined towards the durability technique. Other techniques employed were California bearing ratio, tensile and flexural tests (Noor, 1994) (Fig. 1 and 2).

\section{MATERIALS AND METHODS}

In order to classify the material used in this experimental study, a laboratory investigation program was carried out to evaluate the basic properties and mechanical properties of the untreated soil and the stabilized soil. The asbuton overboulder material was brought from Buton island and sampled at Lawele with coordinate $5^{\circ} 13^{\prime} 53.56^{\prime \prime S}$ and $122^{\circ} 58^{\prime} 0.40^{\prime \prime} \mathrm{E}$. Soft soil used was taken from around Engineering Faculty Hasanuddin University, Gowa, South Sulawesi, Indonesia.

Unconfined compression test and California bearing ratio specimen was remolded according to standard method ASTM D 1883-07 and ASTM D 2166 with 6 


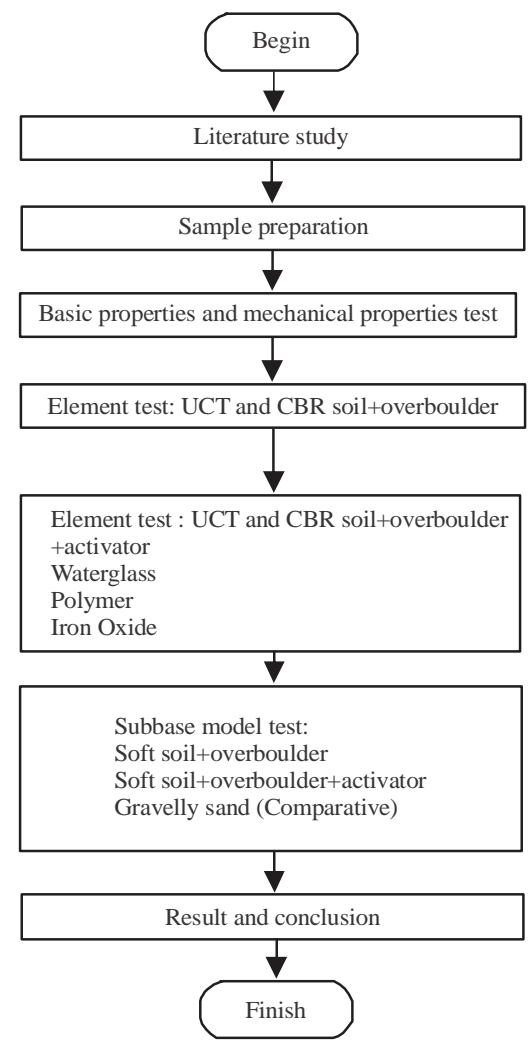

Fig. 3: Flowchart of the research

inches in diameter and 7 inches high for CBR and 2 inches diameter with 4 inches high for UCT. Specimen tested at curing time 7 days, 14 days and 28 days. Generally, the methods used in this research showed in Fig. 3, the flowchart of the research.

\section{RESULTS AND DISCUSSION}

The results of the basic properties and mechanical properties of soft soil are shown in the following Table 1. According to laboratory analyzes, the plastic limit value is $46,35 \%$ and the plasticity index is $14,40 \%$. By linking the plastic limit values to the plasticity index in the plasticity diagram, the soil type is classified as $\mathrm{MH}$ (high plasticity silt) which corresponds to silty soils with high plasticity. Soil grains are dominated by a silt fraction of $34,55 \%$ and clay of $30,25 \%$. By overall properties result, soil used in this study is a fine-grained soil. While the overboulder properties shown in Table 1.

The results of the tests on the physical and mechanical characteristics of the overboulder indicate that it is classified as SP/sand with poor quality. However, the $\mathrm{CBR}$ value shows a higher value than soft soil. While the unconfined compressive strength shows a value slightly lower than soft soil.

The purpose of the compaction test is to obtain the optimum moisture content and maximum dry density in a

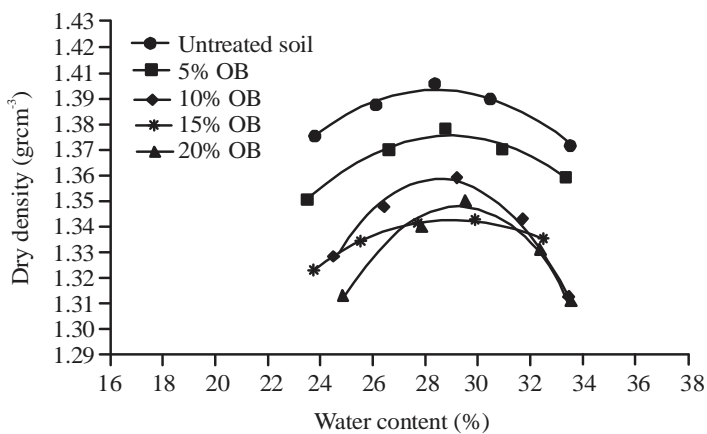

Fig. 4: Standard proctor (Compaction) test result of untreated soil and varied overboulder content

Table 1: Recapitulation of basic properties and mechanical properties of soft soil

\begin{tabular}{|c|c|c|}
\hline \multirow[b]{2}{*}{ Test } & \multicolumn{2}{|l|}{ Test results } \\
\hline & Result value & Units \\
\hline \multicolumn{3}{|l|}{ Basic properties of soft soil } \\
\hline Intial water content & 35.72 & $\%$ \\
\hline Specific Gravity (Gs) & 2.650 & - \\
\hline \multicolumn{3}{|l|}{ Sieve analysis and hydrometer } \\
\hline Sand & 35.20 & $\%$ \\
\hline Silt & 34.55 & $\%$ \\
\hline Clay & 30.25 & $\%$ \\
\hline \multicolumn{3}{|l|}{ Atterbering limits } \\
\hline Liqid Limit (LL) & 60.76 & $\%$ \\
\hline Plastic Limit (PL) & 46.35 & $\%$ \\
\hline Plasticity Index (PI) & 14.40 & $\%$ \\
\hline Shrinkage Limit (SL) & 26.51 & $\%$ \\
\hline \multicolumn{3}{|l|}{ Standard proctor } \\
\hline Maximum dry density $(\gamma d)$ & 1.35 & $\mathrm{gcm}^{-3}$ \\
\hline Optimum Moisture Content (OMC) & 29.84 & $\%$ \\
\hline \multicolumn{3}{|c|}{ Classfication according USCS MH, AASHTO: A-7-5 } \\
\hline Engineering Properties of soft soil: & & \\
\hline Unconfined compressive strength (qu) & 47.35 & $\mathrm{kNm}^{-2}$ \\
\hline California compressive strength (qu) & 7.79 & \\
\hline Elasticity modules (E) & 2064.50 & $\mathrm{kNm}^{-2}$ \\
\hline
\end{tabular}

compaction process. The results of this experiment make it possible to determine the conditions to be fulfilled during compaction in the field. In laboratory experiments, the optimum water content is determined from the graph of the relation between dry density and moisture content. The graph below shows the compaction characteristics of soft soils and soft soils with overboulder variations.

The addition of overboulder shows behavior that tends to show a cross-trend to changes in moisture content and dry weight. As the overboulder increases, the dry density value decreases while the optimum moisture content increases. In Fig. 4, it can be seen that the dry density increases with the increasing percentage of overboulder, the dry density has increased by $4 \%$, compared to the maximum dry density of untreated soil which is $1.35-1.40 \mathrm{gcm}^{-3}$. While the optimum moisture content behavior decreases along with more overboulder added to the mix with an optimum moisture content of untreated soil $29.84 \%$, it decreases by $5.2 \%$ with the addition of $20 \%$ overboulder. The behavior of dry density and moisture content changes shown in Fig. 5. 


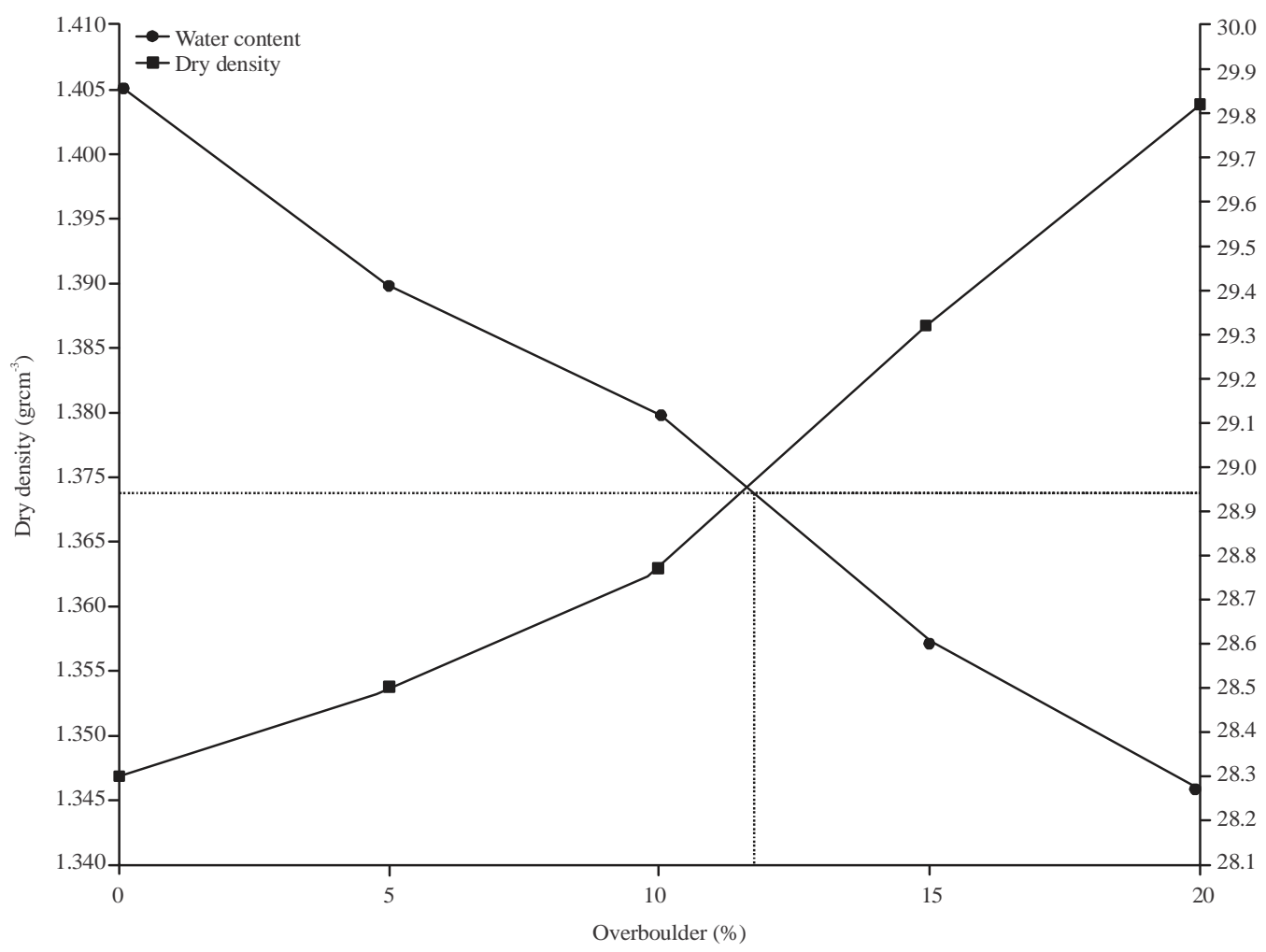

Fig. 5: Relation between overboulder variation to dry density and water content

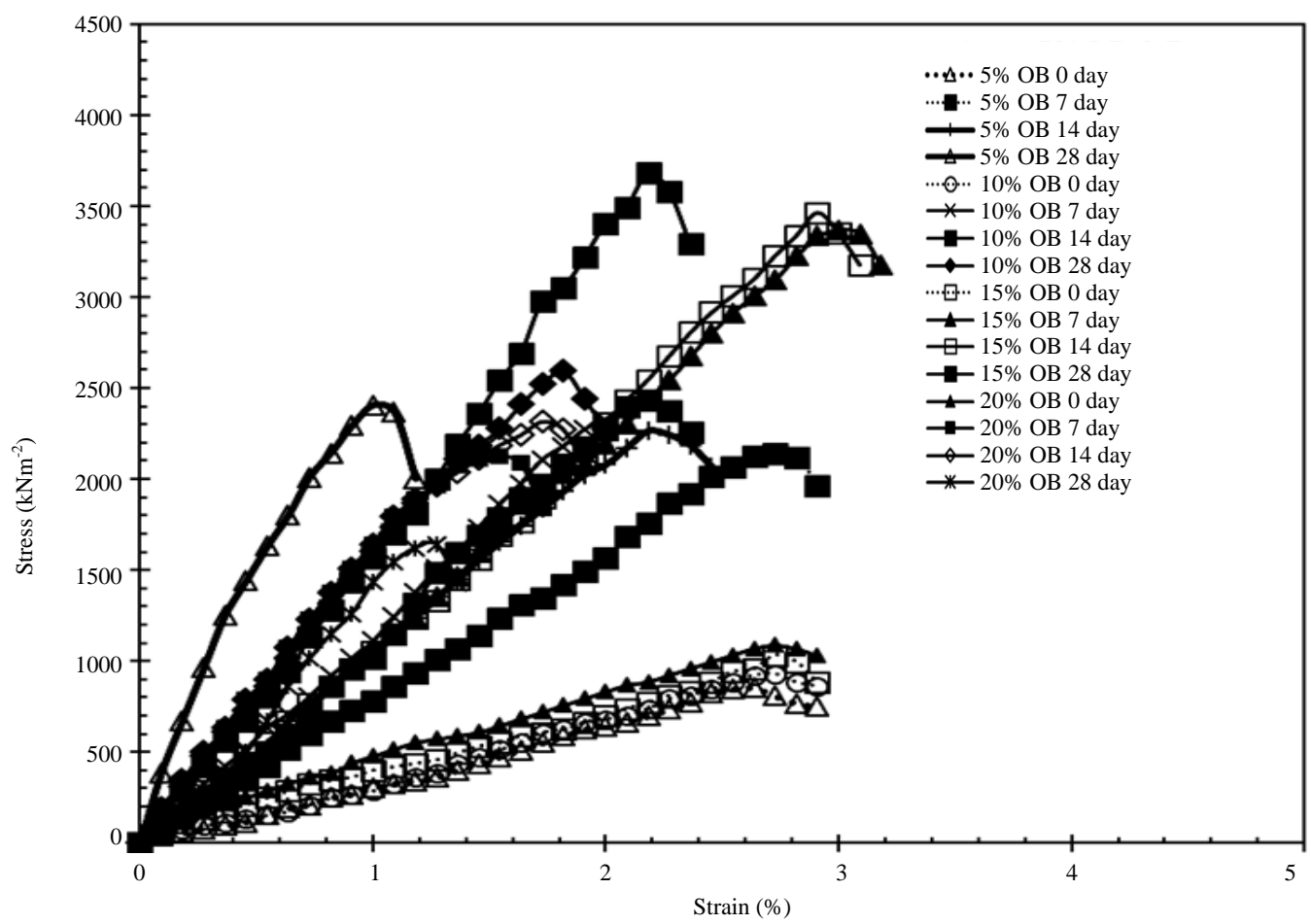

Fig. 6: Recapitulation relation between stress-strain UCT specimen with variation of overboulder percentage and curing time 
J. Eng. Applied Sci., 15 (4): 1043-1051, 2020

Table 2: Recapitulation of basic properties and mechanical properties of overboulder

\begin{tabular}{|c|c|c|}
\hline \multirow[b]{2}{*}{ Test } & \multicolumn{2}{|l|}{ Test results } \\
\hline & Result value & Units \\
\hline \multicolumn{3}{|l|}{ Basic properties of overboulder asbuton: } \\
\hline Specific Gravity (Gs) & 2.650 & - \\
\hline \multicolumn{3}{|l|}{ Sieve analysis and hydrometer } \\
\hline Sand & 81.040 & $\%$ \\
\hline Silt & 13.700 & $\%$ \\
\hline Clay & 5.160 & $\%$ \\
\hline \multicolumn{3}{|l|}{ Standard proctor } \\
\hline Maximum dry density (yd) & 1.370 & $\mathrm{gcm}^{-3}$ \\
\hline Optimum Moisture Content (OMC) & 19.130 & $\%$ \\
\hline \multicolumn{3}{|l|}{ Classfication according USCS: SP, } \\
\hline \multicolumn{3}{|l|}{$\begin{array}{l}\text { Engineering properties of overboulder } \\
\text { asbuton }\end{array}$} \\
\hline California Bearing Ratio-unsoaked (CBR) & 12.060 & $\%$ \\
\hline
\end{tabular}

Table 3: Recapitulation of UCS value of overboulder-stavbilizr soil Unconfined compressive strength $\left(\mathrm{kNm}^{-2}\right)$

\begin{tabular}{lllll} 
Mix & 0 day & 7 day & 14 day & 28 day \\
\hline Untreated soil & 47.35 & - & - & - \\
$5 \%$ overboulder & 854.73 & 2139.52 & 2264.76 & 2406.73 \\
$10 \%$ overboulder & 929.00 & 2415.74 & 2434.62 & 2595.21 \\
$15 \%$ overboulder & 1032.23 & 3368.72 & 3465.54 & 3680.23 \\
$20 \%$ overboulder & 1088.53 & 2127.53 & 2313.20 & 1638.16 \\
\hline
\end{tabular}

Unconfined compression test is performed to determine the value of UCS (Unconfined Compressive Strength) of the specimen. Specimens were remolded in cylindrical form with a ratio of the sample diameter to the sample height of $1: 2$. In this case, the UCT samples were remolded with a diameter of $5.5 \mathrm{~cm}$ and a height of 11 $\mathrm{cm}$.

The soft soil and overboulder are mixed and compacted according to the maximum dry density and optimum moisture content in each composition. The specimens were then tested based on curing periods of 0 , 7,14 and 28 days. The objectives are to determine the difference when the sample assumed to have reacted well. The unconfined compression tests are carried out based on ASTM D 2166.

Figure 6 increase of the UCS value for the addition of $20 \%$ of overboulder during 0 days of curing reached $1088,53 \mathrm{kNm}^{-2}$ by 7 days curing reached 2127,53 $\mathrm{kNm}^{-2}$ by 14 days curing reached $2313,20 \mathrm{kNm}^{-2}$ and the by 28 days curing reached $1638,16 \mathrm{kNm}^{-2}$. While the untreated soil only shows the UCS value of 47,36 $\mathrm{kNm}^{-2}$. With the addition of $15 \%$ overboulder, the highest UCS value was $3368,72 \mathrm{kNm}^{-2}$ by 7 days of curing period, $3465,54 \mathrm{kNm}^{-2}$ for the 14 days of curing period and $3680,23 \mathrm{kN} / \mathrm{m}^{2}$ for the 28 days of curing period. These results indicate that the addition of $15 \%$ overboulder is the optimal composition (Table 2 and 3).

The unconfined compressive strength of stabilized soft soil increases considerably with the curing time. This is possible due to the velocity of pozzolanic reaction which requires time to undergo coagulation or crystallization and hardening processes which can increase the cohesion, reduce the pores and decrease the
Table 4: Recapitulation of UCS value of overboulder-stabilized soil CBR (\%)

\begin{tabular}{|c|c|c|c|c|}
\hline \multirow[b]{2}{*}{ Overboulder } & & & \\
\hline & 0 & 7 & 14 & 28 \\
\hline$\overline{0}$ & 7.79 & - & - & - \\
\hline 5 & 8.77 & 16.19 & 20.68 & 22.03 \\
\hline 10 & 9.44 & 19.33 & 28.78 & 31.47 \\
\hline 15 & 10.34 & 23.83 & 32.97 & 38.22 \\
\hline 20 & 9.89 & 19.56 & 23.83 & 28.33 \\
\hline
\end{tabular}

Table 5: Unconfined compression test result on varied activator

\begin{tabular}{|c|c|c|c|c|c|}
\hline \multirow[b]{2}{*}{ Overboulder $\%$} & \multirow{2}{*}{\multicolumn{2}{|c|}{--Activator (\%)-- }} & \multicolumn{3}{|c|}{$\begin{array}{c}\text { Unconfined compressive } \\
\text { strength }\left(\mathrm{kNm}^{-2}\right)\end{array}$} \\
\hline & & & 7 & 14 & 28 \\
\hline \multirow[t]{3}{*}{15} & Polymer & 1 & 702.20 & 878.4 & 1075.8 \\
\hline & Polymer & 3 & 1005.8 & 1238.7 & 1405.0 \\
\hline & Polymer & 5 & 1223.3 & 1668.8 & 1764.2 \\
\hline \multirow[t]{4}{*}{15} & Waterglass & 1 & 2145.5 & 2481.6 & 2866.0 \\
\hline & Waterglass & 3 & 2687.4 & 2830.9 & 3179.5 \\
\hline & Waterglass & 5 & 3198.4 & 3394.0 & 3622.2 \\
\hline & Ferro oxide & 1 & 1670.3 & 2481.6 & 3068.8 \\
\hline \multirow[t]{2}{*}{15} & Ferro oxide & 3 & $2053 . .3$ & 2758.0 & 3660.8 \\
\hline & Ferro oxide & 5 & 2425.6 & 3217.4 & 4158.7 \\
\hline
\end{tabular}

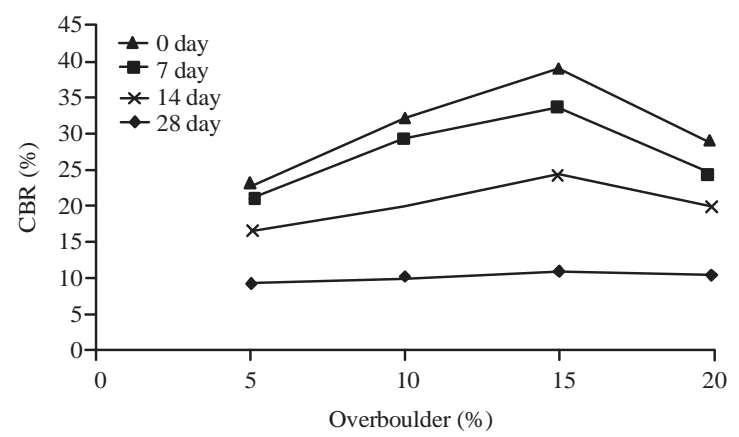

Fig. 7: CBR test result with overboulder variation

permeability, thus, increasing the UCS value. The optimal addition of overboulder is $15 \%$ as it shows the highest increase in UCS value over additions of 5, 10 and $20 \%$. California bearing ratio tests are conducted to determine the strength of a material compared to standard material as a road foundation layer. The samples were remolded in accordance with ASTMD 188307 . As the UCT samples, CBR samples were also tested in stages depending on the curing period. The results of the CBR tests are shown in Table 4.

The results of the CBR test showed relatively similar behavior with changes in the value of the UCS. The highest value of CBR was obtained by adding 15\% overboulder. The CBR value in the 0 days of the curing period is $10,34 \%, 23.83 \%$ in the 7 days of the curing period at 14 days of curing period is $32,97 \%$ and by 28 days of curing period is $38,22 \%$. With these results, it can be concluded that the optimal composition of the overboulder in the soil is $15 \%$ (Fig. 7 and 8 and Table 5). 


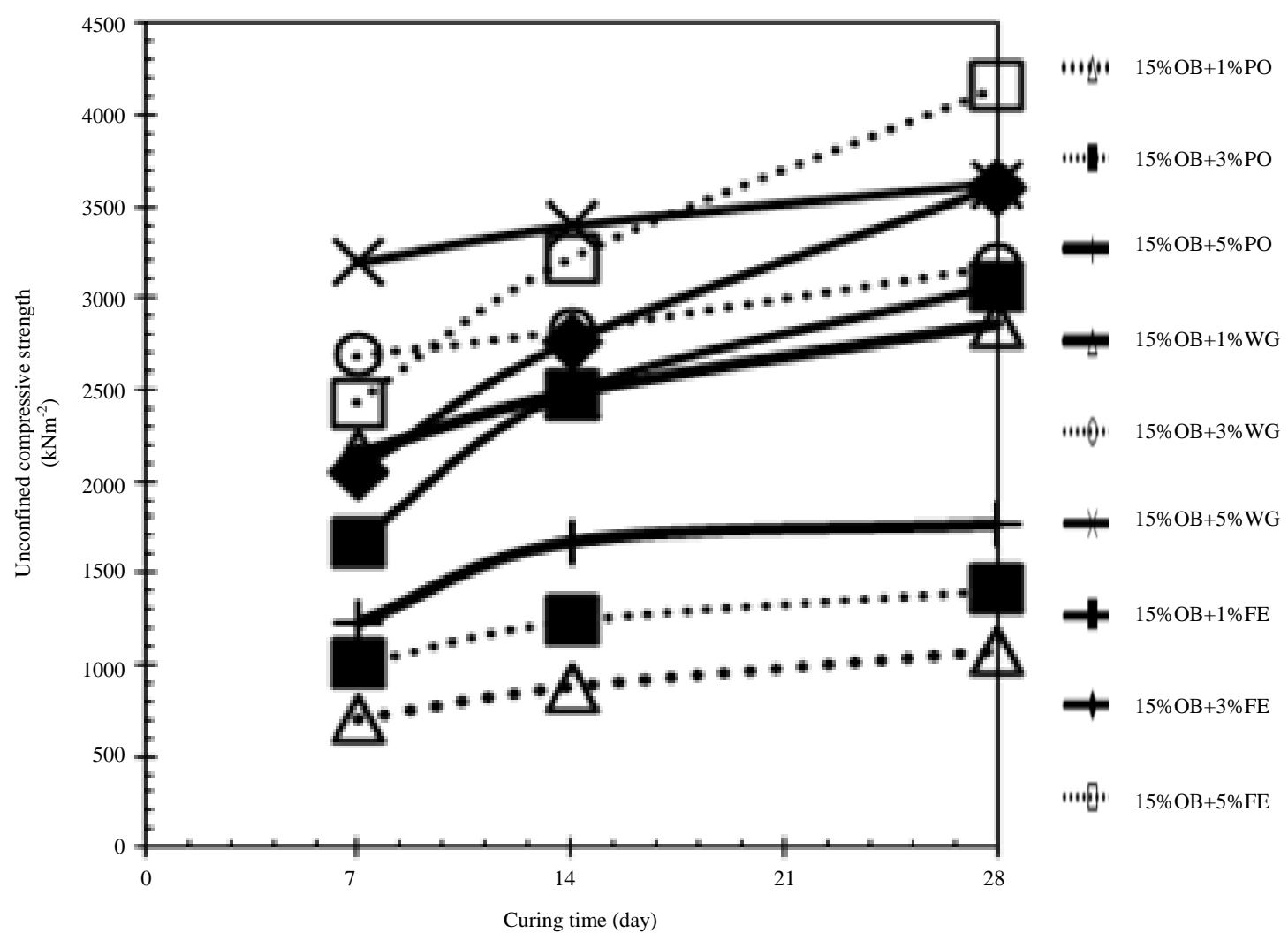

Fig. 8: Unconfined compression test result with varied activators

After obtaining the optimum composition, the performance of the overboulder as a stabilizer can be activated using other additives. To determine the appropriate activator used to improve overboulder stabilization, several options are used including:

- Polymer

- Waterglass

- Ferro oxide

Due to the optimal addition of overboulder was $15 \%$, the ratio of stabilizer/activator material is limited to $20 \%$ to obtain the optimum ratio. The specimens were remolded and aged for a minimum of 7 days and a maximum of 28 days taking into account the chemical reactions occurring between the soil, the stabilizers and the activators. After obtaining a number of possible options, the test is performed by the California bearing ratio test and unconfined compression test to determine the influence of activator to mechanical value.

The addition of ferro-oxide to the composition of the mixture shows a linear tendency to increase with the addition of ferro-oxide, similar to the addition of polymers and water glass. Overall, the results of the unconfined compressive strength of overboulder stabilized soil activated by ferro-oxide show an upward trend. The highest value was obtained by adding $5 \%$ ferro oxide with unconfined compressive strength value increasing to $4158,7 \mathrm{kNm}^{-2}$. These results are superior to soft soils stabilized by Overboulder and superior to soft soils stabilized by polymer and water glass activations. This is probably due to the presence of FE atoms that create ionic bonds between metal compounds in this case, alumina contained in the soil, ionic bonds more stable than the covalent coordination bonds formed between different compounds of phase such as pozzolan compounds. It can't be said that the addition of ferro oxide functions in this case as a catalyst because the reaction rate and the ratio of the increase in the load capacity are relatively the same as those of the other activating materials (Fig. 9).

The UCS value and the soil CBR value increase after the addition of overboulder and activation. Based on the tests carried out, the optimum addition of the overboulder was $15 \%$ with an increase in the unconfined compressive strength up to $4158,7 \mathrm{kNm}^{-2}$ and a CBR value up to $62.95 \%$. The presence of an activating material increases the mechanical index of the soil. According to the test results, the highest bearing capacity value was achieved with a composition of $5 \%$ iron oxide and $15 \%$ overboulder. The value of unconfined compressive strength increased by $113 \%$ compared to $15 \%$ overboulder-stabilized soil. CBR values increased by $165 \%$ over overboulder-stabilized soils. This shows that 


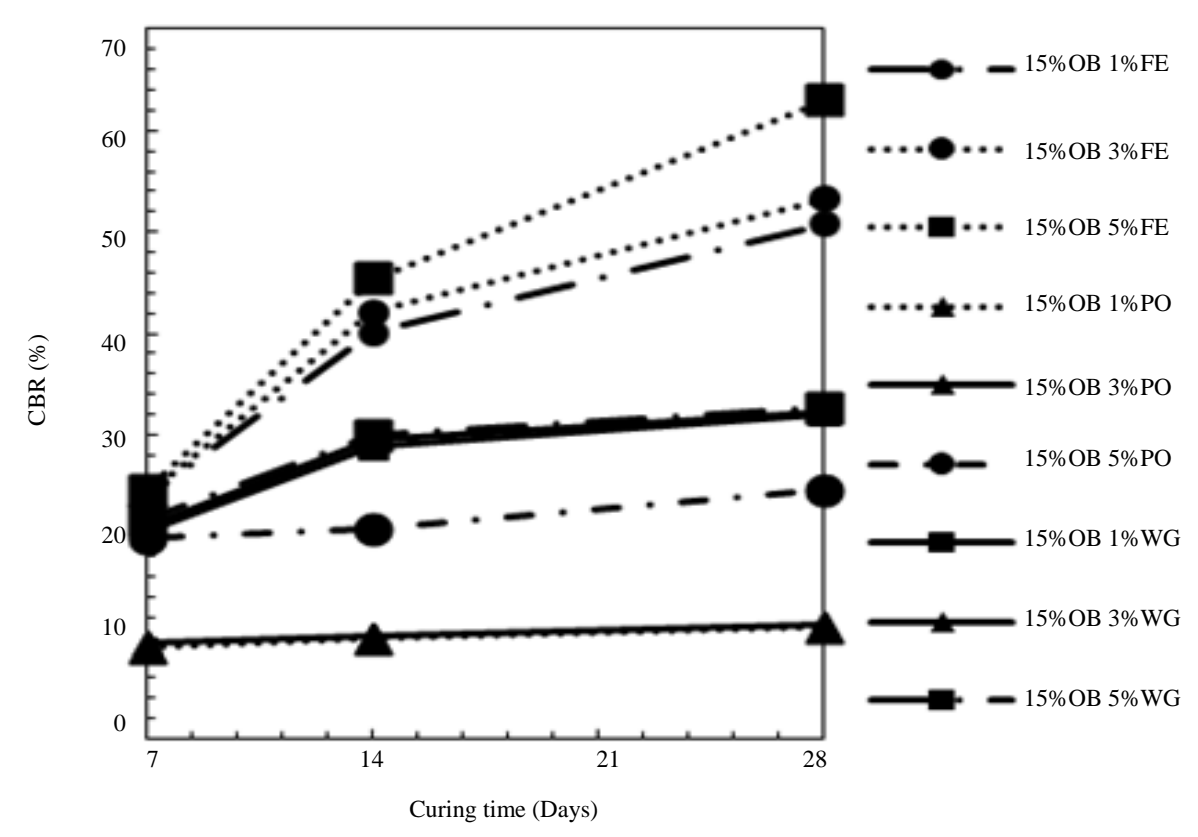

Fig. 9: CBR test reslts with activator variation

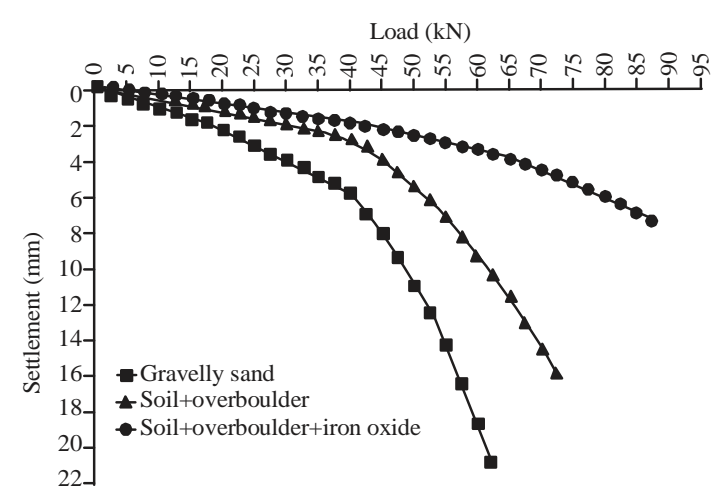

Fig. 10: Model test result with material variation

ferro oxide is the most appropriate material for activating the performance of overboulder as a soil stabilizing material.

In the model test of soft soil stabilization using overboulder as a subbase layer, the stabilized soil remolded and compacted statically with $20 \mathrm{~cm}$ thick. Under the subbase layer, the subgrade layer with a thickness of $50 \mathrm{~cm}$ is also modeled. While the elongated dimensions of the model are $150 \mathrm{~cm}$ with a width of $60 \mathrm{~cm}$.

The test is carried out after 7 days of curing time of the stabilized soil sample so that the CBR value meets the technical criteria. The CBR value of each layer is monitored using a dynamic cone penetrometer. In addition, for loading tests, the samples were loaded with a $20 \mathrm{~cm}$ diameter bearing plate until collapse.
The collapse occurs when the settlement continues but the load does not show an increase. The model test divided into 3 parts, namely gravelly sand as a conventional subbase layer and used for comparison, overboulder-stabilized soil with 7 days of curing time and overboulder-stabilized soil activated by iron oxide with 7 days of curing time.

The performance of gravelly sand as a conventional subbase layer used has a CBR value of $22.18 \%$, thus meeting the criteria as a sub-base layer with a minimum criterion of $20 \%$. While the overboulder-stabilized soil used has a CBR value of $23.83 \%$. While the overboulder-stabilized soil with the addition of iron oxide has a CBR value of $24.50 \%$. The performances of the three different types of materials will then be compared. The results of the three materials used as a subbase layer shown in Fig. 9 and Table 6.

From the results of the comparison of the three materials shown in Fig. 10, the overboulder-stabilized activated by iron oxide has the best performance. The value of the reaction modulus indicates $195,86 \mathrm{kNm}^{-2} \mathrm{~mm}^{-1} \mathrm{~mm}$. The modulus value is $262 \%$ times greater than the modulus of the gravelly sand and $146 \%$ times greater than the modulus of overboulder-stabilized soil. When associated with the CBR value, the modulus and the CBR value are directly proportional. The higher the CBR value, the higher the soil reaction modulus will be. The description is illustrated in Fig. 11 and Table 7.

Adding overboulder as soft soil stabilizer has been shown to improve the mechanical properties of soft soils 


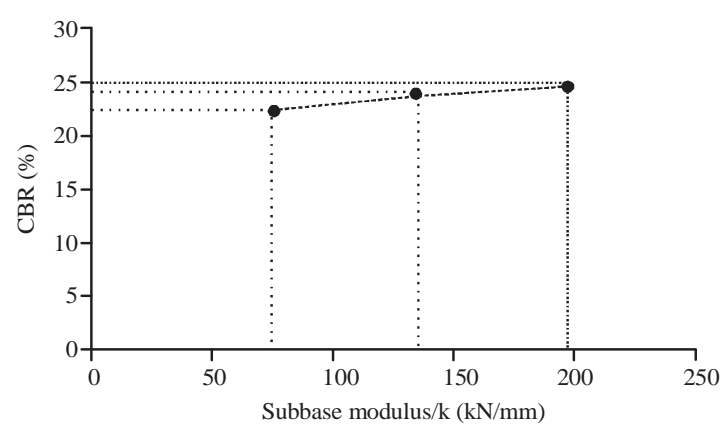

Fig. 11: Relation between CBR and modulus value

Table 6: CBR test result on vried activator

\begin{tabular}{|c|c|c|c|c|c|c|}
\hline \multirow[b]{2}{*}{ Overboulder (\%) } & & & \multicolumn{4}{|c|}{ CBR (\%) } \\
\hline & --Activator (o & & 0 & 7 & 14 & 28 \\
\hline$\overline{15}$ & Polymer & 1 & 8.09 & 8.99 & 9.890 & 11.02 \\
\hline 15 & Polymer & 3 & 8.54 & 9.44 & 10.120 & 11.24 \\
\hline 15 & Polymer & 5 & 9.89 & 19.78 & 20.640 & 24.50 \\
\hline 15 & Waterglass & 1 & 10.19 & 20.53 & 28.780 & 32.07 \\
\hline 15 & Waterglass & 3 & 10.64 & 20.98 & 29.530 & 32.22 \\
\hline 15 & Waterglass & 5 & 11.24 & 21.58 & 29.970 & 32.67 \\
\hline 15 & Ferro oxide & 1 & 11.09 & 23.98 & 40.020 & 50.81 \\
\hline 15 & Ferro oxide & 3 & 11.54 & 24.13 & 42.110 & 53.21 \\
\hline 15 & Ferro oxide & 5 & 10.64 & 24.50 & 45.410 & 62.95 \\
\hline
\end{tabular}

Table 7: Subbase nodulus value

\begin{tabular}{lccc}
\hline Settlement & $\begin{array}{l}\mathrm{q} \\
\left(\mathrm{kNm}^{-2}\right)\end{array}$ & $\begin{array}{c}\mathrm{k}\left(\mathrm{kNm}^{-2}\right)\left(\mathrm{mm}^{-1}\right) \\
\text { empirical }\end{array}$ & $\begin{array}{c}\mathrm{k}\left(\mathrm{kNm}^{-2}\right) \\
\left(\mathrm{mm}^{-1}\right) \\
\text { corrected }\end{array}$ \\
\hline 5.5 & 1369.427 & 248.99 & 74.70 \\
3.5 & 1560.510 & 445.86 & 133.76 \\
3.0 & 1958.599 & 652.87 & 195.86 \\
\hline
\end{tabular}

in both element test and the model test. The CBR value increased significantly up to $38,22 \%$ and the unconfined compressive strength reached $3680,23 \mathrm{kNm}^{-2}$. This indicates that the overboulder can be used as a substitute material for the cement to stabilize the road foundation layer. After the addition of ferro oxide, the $\mathrm{CBR}$ value rose to $62,95 \%$ and the UCS value to $4158,7 \mathrm{kNm}^{-2}$.

\section{CONCLUSION}

The results of the physical and mechanical properties show that overboulder was classified as sand/SP based on the unified soil classification system. The value of the mechanical index of unconfined compressive strength was $60,79 \mathrm{kNm}^{-2}$ with a CBR value of $12,06 \%$. Overboulder contains mainly lime and silica, so, it can be used as a stabilizing material for loose soil instead of cement or lime.

The UCS and CBR value increases after the addition of overboulder and activation. Based on the tests carried out, the optimum addition of the overboulder was $15 \%$ with the UCS value of $3680,23 \mathrm{kNm}^{-2}$ and CBR value of $38,22 \%$. The presence of an activating material increases the mechanical index of the soil. According to the test results, the highest bearing capacity was achieved with a composition of $5 \%$ iron oxide and $15 \%$ overboulder. The UCS value increased by $113 \%$ compared to $15 \%$ overboulder-stabilized soil. The CBR value increased by $165 \%$ over $15 \%$ overboulder-stabilized soil. This shows that ferro oxide is the most appropriate material for activating the performance of overboulder as a soil stabilizing material.

The result of the model test with overboulder stabilized soil activated by iron oxide showed that the deepest settlement was $7.51 \mathrm{~mm}$. The maximum load reached was $87.5 \mathrm{kN}$. The equivalent load and the equivalent settlement are then linked via a graph of the relation between load and settlement to obtain the value of the reaction modulus. An equivalent load of $61.5 \mathrm{kN}$ with a decrease of $3 \mathrm{~mm}$ gives a reaction modulus of $195,86 \mathrm{kNm}^{-2}$ per mm. This result is even better compared to the results obtained with the gravelly sand and the overboulder-stabilized soil. The maximum load increases $15 \mathrm{kN}$. While the settlement of subbase itself was reduced by $8.37 \mathrm{~mm}$. These results indicate that soft soil stabilization using overboulder activated by iron oxide provides better performance as a sub-base layer compared to gravelly sand and overboulder-stabilized soil if used as a subbase.

\section{ACKNOWLEDGEMENT}

The researchers gratefully acknowledge the financial support from LPDP (Lembaga Pengelola Dana Pendidikan), Grant No: PRJ-5196/LPDP.3/2016. We'd like to thank Geo-Environmental Laboratory teams of Hasanuddin University and colleagues for their technical support during the experimental works.

\section{REFERENCES}

Bandara, W.W., W.K. Mampearachchi and K.H.S.M. Sampath, 2017. Cement stabilized soil as a road base material for use in Sri Lankan roads. J. Inst. Eng. Sri Lanka, 50: 21-29.

Croney, D. and P. Croney, 1997. The Design and Performance of Road Pavements. 3rd Edn., McGraw-Hill, UK., ISBN: 978-0070144514, Pages: 528.

Dupas, J.M. and A. Pecker, 1979. Static and dynamic properties of sand-cement. J. Geotech. Eng. Div., 105: 419-436.

FHA., 1980. Soil Stabilization in Pavement Structures: A User's Manual. Volumes 1-2, Report No. FHWA-IP-80-2, Federal Highway Administration, Washington DC., USA.

Ingles, O.G. and J.B. Metchalf, 1972. Soil Stabilization: Principles and Practice. Butterworth-Heinemann, Australia, ISBN:9780409482157, Pages: 374. 
Little, D.N. and S. Nair, 2009. Recommended practice for stabilization of subgrade soils and base materials. Final Task Report for NCHRP Project 20-07, National Cooperative Highway Research Program, Transportation Research Board of the National Academies, Texas Transportation Institute, Texas, USA. http:// onlinepubs. trb.org/onlinepubs /nchrp/nchrp_w144.pdf.

Mamun, M.M.H., M.F.M. Ovi, F. Akhter, S. Barua, M. Ahmed and T.J. Nipa, 2016. Improvement of sub base soil using sand-cement stabilization. Am. J. Civ. Eng., 4: 241-246.
Noor, M.J.M.M., 1994. Durability and strength characteristics of cement stabilized modified Melaka series. J. Islamic Acad. Sci., 7: 137-141.

RDA., 1989. Standard Specification for Construction and Maintenance of Road and Bridges (SSCM). Road Development Authority (RDA), Battaramulla, Sri Lanka.

TRL., 1977. Technical basis of austroads pavement design guide. Transport Research Laboratory, Crowthorne, UK. 